\title{
Symbiotic pathways of carbon in coral reef ecosystems
}

\author{
Present status and future prospects
}

\author{
D. L. TAYLOR \\ Rosenstiel School of Marine and Atmospheric Science, University of Miami; \\ Miami, Florida, USA
}

\begin{abstract}
KURZFASSUNG: Symbiotische Wege des Kohlenstoffs in Korallenriff-Ökosystemen. Gegenwärtiger Status und zukünftige Aussichten. Die metabolische Leistungsfähigkeit des Okosystems Korallenriff basiert zu einem wesentlichen Teil auf der unmittelbaren zellulären Integration von Primärproduzenten und Konsumenten in der symbiotischen Verbindung von Algen und Korallen. Diese Form des Zusammenlebens zweier Organismen stellt ein charakteristisches Merkmal der tropischen Korallenriffe dar und spielt eine Schlïsselrolle bei der Aufrechterhaltung des Ernährungsgleichgewichts innerhalb dieses Okosystems. Die gegenwärtigen Kenntnisse in bezug auf die Primärproduktion und den Weg des durch die Symbionten fixierten Kohlenstoffs werden besprochen. Methoden für In-situ-Forschungen werden an Hand der bisher erzielten Ergebnisse bewertet, und die Aussichten, die Energietransformation in den Lebensgemeinschaften im Korallenriff zu erfassen, diskutiert.
\end{abstract}

\section{INTRODUCTION}

Coral reefs are stable, species diverse, well-adapted ecosystems that are among the most productive of all natural communities (ODUm 1971). Available estimates place productivity between $1500-3500 \mathrm{~g}$ carbon/m²/year (STODDART 1969). These values are at least the equivalent of both modern agriculture, and laboratory algal cultures (ODum \& ODum 1959). A substantial portion of the total organic carbon fixed annually is due to the near universal presence of symbiotic algae in associations with invertebrates. Among those, the hermatypic corals are by far the most important, due to their formation of geologically stable structures. Nevertheless, other organisms, notably protozoans, sponges, anemones, soft corals (Octocorallia) and turbellarians, are by no means inconsequential in terms of the total energy input of species in symbiosis (TAYLOR 1972, 1973). Under normal conditions, most of these (including hermatypic corals) will produce more organic carbon than they consume in a given $24 \mathrm{~h}$ period (e. g. Odum et al. 1959, Kanwisher \& Wainwright 1967, TaYlor 1971). Clearly, the inclusion of primary producers and consumers in the same functional unit enhances metabolic efficiencies within the organisms of the reef community. Unfortunately, we are not in a position to judge its importance at the present time. 
Laboratory studies of symbiotic algae in vivo and in vitro have substantially increased our knowledge of the nutritional and biochemical aspects of associations formed with invertebrates, making it possible to assess the quality as well as the quantity of materials synthesized by functional symbiotic units (for reviews see Muscatine 1972, 1973, TAYlor 1972, 1973). In contrast, there is little quantitative or qualitative information on trophic cycles within the reef community based on productive symbiotic elements (BAKus 1969, STODDART 1969). To a large extent, this is due to the fact that the pathways themselves are generally unknown. This problem has recently been explored in a review by Goreau et al. (1971). They point out, that in the face of the low trophic potential of tropical oceanic waters, high localized productivity in reefs can only be achieved through coupled internal recycling systems that reduce losses of free energy to a minimum and maintain local nutrient levels at high steady-state values. In this situation, algal-invertebrate symbioses would appear to be a principal, and highly efficient, source of new nutrients and energy. It seems appropriate therefore to explore their productive potential, determine the quantity and quality of material translocated into major nutrient pathways on the reef and assess potential recycling systems. The present work is an attempt in this direction. It is hoped that a review of past and present studies of the path of symbiotically derived carbon in coral reefs will point out new problems and lead towards new techniques for studying this aspect of reef metabolism.

\section{PRODUCTIVITY OF SYMBIOTIC ASSOCIATIONS}

Our knowledge of overall coral reef productivity is based principally on flow studies of total community metabolism $\left(\mathrm{O}_{2}\right.$ and $\mathrm{CO}_{2}$ exchange) in atoll reef flats possessing unidirectional currents (SARGENT \& AUSTIN 1949, 1954, ODUM \& ODUM 1955, Kohn \& Helfrich 1957, Odum et al. 1959, Gordon \& Kelly 1962, Milliman \& MAHNKEN 1969). The same technique has been applied to isolated stands of coral (Porites) and anemones (Zoanthus) associated with algal symbionts, and yields extraordinarily high values (18 $\mathrm{g}$ carbon $/ \mathrm{m}^{2} /$ day) (ODum et al. 1959). These may be indicative of the scale of symbiotic production in these shallow water areas, but in the absence of supporting studies their value is in doubt. Changes in the $\mathrm{CO}_{2}$ system of seawater as it passes over the reef may also be monitored in a similar fashion, and the data partitioned to yield information on inorganic $\mathrm{CaCO}_{3}$ precipitation and solution, and organic carbon production and respiration (PARK 1969, SMITH 1972). Such a method might be adapted for the in situ study of discrete corals. In general, however, use of these techniques is necessarily restricted to the shallow-water zones of characteristically oriented reefs. At best, they can only provide a general overview of reef flat metabolism, which cannot yield information on the magnitude of symbiotic production, and ignores the major portion of the reef biomass existing below 5 meters (Goreau et al. 1971).

Productivity measurements of corals, gorgonians and their algal symbionts have been carried out using in vitro systems, and WINKLER (FRANZISKET 1964, 1969) or polarographic techniques for $\mathrm{O}_{2}$ determinations (KANWISHER \& WAINWRIGHT 1967, 
RofFMan 1968). Using the latter technique, KANWISHER \& WAINWRIGHT (1967) report productivity values between $2.7-10.2 \mathrm{~g}$ carbon $/ \mathrm{m}^{2} /$ day for hermatypic corals and gorgonians. The restraints of the experimental chamber and handling would tend to minimize these data. Similar values may be derived from the results of other authors (RoffMan 1968, Franzisket 1969); and all agree well with the data obtained from flow studies on the reef flat (see above). Attempts to carry these techniques onto the reef in situ have been few, although encouraging data has been obtained despite apparent difficulties.

$\mathrm{O}_{2}$ production by six species of coral inhabiting Florida and Jamaican reefs has been examined in situ using the WINKLER method. At the start of each experiment, small corals $(5-10 \mathrm{~cm}$ diameter) were carefully removed from the reef and placed in clear polyethylene bags which had been prepared previously with a rubber tire patch intended to serve as a syringe port. The bags were then tied off at predetermined points in order to ensure comparable volumes of water within the bag, and left to incubate. Samples were taken at 30 minute intervals during a 3 hour period around midday, using glass syringes fitted with stainless steel needles. Experiments were carried out at depths of $5,10,15$ and 20 meters. The results appear in Table 1 , and are expressed as grams carbon $/ \mathrm{m}^{2} / \mathrm{day}$. It is interesting to note that major framebuilding types exhibit similar rates at the depths studied, while the more fleshy, solitary species of mussids, Montastrea angulosa and Scolymia lacera, have much lower rates. This is probably due to the presence of fewer symbionts in these species, but it may also be a reflection of each animal's metabolic influence over the apparent rate of carbon fixed by its algal symbionts. Either could be an important consideration in the overall assessment of coral production based on rates derived from individual species and composite communities. Similarly, depth and depth-related light intensities

Table 1

Productivity of six species of reef coral. Data on $\mathrm{O}_{2}$ production in situ. Converted to g carbon $/ \mathrm{m}^{2} /$ day. (See text)

\begin{tabular}{|c|c|c|c|c|}
\hline \multirow[b]{2}{*}{ Species } & \multicolumn{4}{|c|}{ Meters } \\
\hline & 5 & 10 & 15 & 20 \\
\hline Porites astreoides & 13.3 & 13.9 & 13.8 & 12.4 \\
\hline Montastrea annularis & 9.8 & 12.5 & 14.2 & 12.1 \\
\hline M. cavernosa & 10.6 & 11.8 & 11.7 & 10.3 \\
\hline Siderastrea radians & 12.1 & 12.6 & 13.7 & 13.1 \\
\hline Mussa angulosa & 1.9 & 2.5 & 4.1 & 3.0 \\
\hline Scolymia lacera & 2.7 & 3.7 & 5.9 & 3.7 \\
\hline
\end{tabular}

also appear to affect the maximum values obtained (Table 1). This is particularly true of deeper stations. Recent studies show that when light values exceed saturating intensities, productivity can also be affected (see Barnes \& TAYLOR 1973). Further investigation of these factors affecting symbiotic productivity is required.

Simpler and more rapid measurements of $\mathrm{O}_{2}$ production could be achieved through polarographic techniques adapted for use underwater. Although the technology exists, it has not been effectively exploited in studies of this nature. Combined with suitable recording devices and appropriately designed experimental chambers, 
$\mathrm{O}_{2}$ polarography could provide an important means of continuously monitoring $\mathrm{O}_{2}$ exchange in a variety of reef organisms and communities at all practical working depths.

Radiotracer experiments involving the photosynthetic fixation of ${ }^{14} \mathrm{CO}_{2}$ are powerful tools for assessing productivity of symbiotic elements in coral reefs, and determining nutrient pathways emerging from the primary symbiotic unit (see below). Although these methods have been used extensively in laboratory studies of symbiont photosynthesis and carbon translocation within the symbiotic unit (i.e. host + symbiont) (SMith et al. 1969, Muscatine 1972, 1973, Taylor 1973), they have not had wide acceptance as a means of measuring productivity in situ. This is surprising, in view of the fact that ${ }^{14} \mathrm{CO}_{2}$ uptake is a standard oceanographic method for determining primary productivity.

Some preliminary experiments on rates of ${ }^{14} \mathrm{CO}_{2}$ fixation by four coral species from Jamaican reefs have been carried out using the polyethylene bags already described. In each experiment, final activities of $\sim 0.9 \mu \mathrm{Ci} / \mathrm{ml}$ seawater were used (determined by withdrawing a water sample at the start of the incubation). The methods of analysis follow those outlined by STRICKLAND \& Parsons (1968). Six corals of each species collected at a depth of 10 meters were incubated in separate bags. One of these was sampled every $1 / 2$ hour during the course of the experiment and analyzed

Table 2

Uptake of ${ }^{14} \mathrm{CO}_{2}$ by four species of reef coral. Averages taken from 3 samples of the coral surface, expressed as g carbon $/ \mathrm{m}^{2} /$ hour. Standard deviation \pm 0.09 . (See text)

\begin{tabular}{|lllllll|}
\hline Species & 30 & 60 & 90 & 120 & 150 & 180 \\
\hline Montastrea annularis & 0.3 & 0.5 & 0.6 & 0.7 & 0.6 & 0.6 \\
M. cavernosa & 0.3 & 0.5 & 0.5 & 0.5 & 0.6 & 0.6 \\
Siderastrea radians & 0.4 & 0.5 & 0.6 & 0.7 & 0.7 & 0.7 \\
Dichocoenia stokesii & 0.3 & 0.4 & 0.5 & 0.6 & 0.5 & 0.6 \\
\hline
\end{tabular}

according to the methods described by CoOKSEY \& CoOKSEY (1972). The results are expressed in Table 2, as rates of uptake for each coral sample taken in a given time period. These show that the rate at which coral tissues are labelled is fairly constant throughout the experimental period. Individual productivity values for the maximum rates shown range between 16.8 and $12.0 \mathrm{~g}$ carbon $/ \mathrm{m}^{2} /$ day, and are consistent with the data obtained in WINKLER studies. These also compare well with the results of flow studies over shallow coral stands (ODum et al. 1959).

\section{CONSERVATION, TRANSLOCATION AND RECYCLING OF NUTRIENTS AND ENERGY DERIVED FROM SYMBIOTIC ASSOCIATIONS}

Given an eventual understanding of the magnitude of organic carbon production by algal-invertebrate associations on the reef, it is important to know (1) the carbon requirements of the symbiosis itself, and (2) the retention time and turnover 
rate of photosynthetically fixed carbon in the symbiosis. Laboratory studies show that the carbon fixed by symbiont photosynthesis is rapidly translocated to the host. Much of this is in the form of low molecular weight cellular intermediates and lipids, having rapid turnover in the host's tissues. The remainder has a longer retention time and is characterized by trichloroacetic acid and alcohol insoluble compounds (SMITH et al. 1969, Muscatine \& Cernichiari 1969, Trench 1971a, b, c, Muscatine et al. 1972). Utilization of these products by the host has been poorly studied, although opinions on the matter have been the source of considerable controversy in recent years (Johannes et al. 1970, Goreau et al. 1971). Details of host utilization, and possible recycling within the association itself, are needed before retention times, rates of translocation to the reef community and quality of the translocate can be determined. Some insight into the problem may be gained from a recent in situ study of carbon turnover in the reef corals Montastrea annularis and Siderastrea siderea carried out during the TEKTTTE II Program (Cooksey \& Cooksey 1972). After labelling in polyethylene bags for 3 hours, specimens were removed from the label and initial samples taken. Tissues were extracted in $70 \%$ ethanol and $6 \mathrm{~N} \mathrm{NH} \mathrm{NH}_{4} \mathrm{OH}$. Subsequent samples were removed at intervals during a period of 11 days. Although some slight differences were observed between the two species, the results show that during the first 3 hours after removal from the label activities in both tissue extracts increased. Later, the activity in the ethanol extract declined, while that in the ammonia extract continued to rise, suggesting that unstable intermediates in the former were being converted to more stable compounds found in the ammonia extracts. During the first period of darkness, activities dropped to less than $1 / 2$ the original values, but declined very little during the remaining 10 days. The authors concluded that after the initial loss of radioactive carbon from a pool close to respiratory pathways, carbon was lost more slowly, with a half-life of 2 weeks to one month (Cooksey \& COOKSEY 1972). These experiments are of considerable interest, since they provide the first available data on the longevity of symbiotically fixed carbon in host species on the reef. The observation that more than $1 / 2$ of the original label was lost from pools associated with respiratory pathways suggests that very little of this symbiotically fixed carbon may be passed on to other elements of the reef community. However, studies on the release of dissolved organic compounds by symbiotic hosts are required before any conclusions can be reached in this regard. The data also suggest that hostrespired $\mathrm{CO}_{2}$ is apparently not refixed by symbiont photosynthesis to any significant degree. Considering the cellular nature of the hosts, and the prevailing $\mathrm{CO}_{2}$ balance of seawater, this is not surprising.

These losses may not be as important as the ultimate fate of the more stable compounds remaining with the coral tissues and their associated algal symbionts. It can be postulated that these materials will enter the reef ecosystem principally in the form of suspended organic matter that could be readily assimilated by the numerous suspension and particle feeders present on the reef (Goreau et al. 1971). Coral predators, such as echinoderms and acanthurid and scarid fishes, provide the most direct route into the food chain, contributing substantially to organically rich carbonate sediments and the particulate organics of the water column (BARDACH 1961). Excretion of large quantities of mucus by coral, gorgonian and sponge hosts would 
also provide a substantial input of organic carbon that could be readily utilized by microorganisms, and easily converted into colloidal and particulate suspended matter (Marshall 1965, Johannes 1967, Goreau et al. 1971). The almost continual excretion of algal symbionts by hosts (TAYLOR 1969), and the periodic release of planulae and gonadal products would also form an important source of food and nutrients available to the reef community within the circulating boundary waters.

Once released from the symbiotic unit, these nutrients could be recycled back to the host via bacterial or fungal decomposers (DISALvo 1971a, b), conventional predator food chains, or through hosts feeding on particulate suspended matter derived as noted above (Goreau et al. 1970, Goreau et al. 1971, Muscatine 1973). Soluble organic compounds excreted by the symbiotic association itself (see above), or originating from other elements of the reef, could be assimilated heterotrophically by the algal symbionts (TAYLOR 1973), or utilized directly by the animal host (GOREAU et al. 1971). As yet, there is no conclusive proof that dissolved organics in concentrations normally encountered on the reef, can be recycled in this fashion. However, corals and gorgonians appear to be well adapted to this mode of nutrition (Goreau et al. 1971), and there is some data substantiating heterotrophy by algal symbionts. New experimental studies should be directed in this area.

\section{CONCLUSIONS}

This examination of productivity by symbiotic associations in coral reef ecosystems is at best only a preliminary statement of our present knowledge. It has been possible to demonstrate their productive potential, and place this within the context of theoretical nutrient pathways within the total community. More than anything else, however, it has illustrated the need for more intensive and broadly based studies in this area. Various in situ techniques are available for the measurement of primary productivity in the symbiotic elements of the reef. These can be employed to refine current estimates, and extend baseline data into the deeper and more significant (in terms of biomass) regions which have been historically ignored (STODDART 1969, Goreau et al. 1971). "Autotrophy" of symbioses involving unicellular algae is a valuable experimental asset, which makes the use of ${ }^{14} \mathrm{CO}_{2}$ to study productivity and nutrient pathways within the reef community a powerful technique that will find increasing use in future. Combined laboratory and field studies using these methods should establish which of the pathways noted are actually utilized in nature. Their elaboration, along with that of associated conservation and recycling systems, should establish the essential nature of algal-invertebrate symbiosis in the continuing survival of coral reefs as nutrient rich, productive oases in impoverished tropical seas.

\section{SUMMARY}

1. Productivity of algal-invertebrate symbiosis in coral reef ecosystems is discussed, and current methods of analysis described. 
2. Translocation within the symbiosis, apparent rates of turnover, the retention time of carbon fixed in photosynthesis and the excretory pathways leading to the reef community are examined. Possible mechanisms for recycling carbon back to the level of the primary producers are presented.

3. Future prospects for in situ studies of the "coral reef problem", and the requirements for substantiative data in these areas are discussed.

Acknowledgements. Portions of the work reported here were supported by grants from the National Science Foundation (GB-19790) and the Browne Fund of the Royal Society. This paper is Contribution No. 1573 from the Rosenstiel School of Marine and Atmospheric Science, Miami.

\section{LITERATURE CITED}

Bakus, G. J., 1969. Energetics and feeding in shallow marine waters. Int. Rev. gen. exp. Zool. $4,275-239$.

Bardach, J. E., 1961. Transport of calcareous fragments by reef fishes. Science, N. Y, 133, 98-99.

BarNes, D. J. \& TAYLOR, D. L., 1973. In situ studies of calcification and photosynthetic carbon fixation in the coral, Montastrea annularis. Helgoländer wiss. Meeresunters. 24, 284-291.

CooKsEY, K. E. \& CoOKSEY, B., 1972. Turnover of photosynthetically fixed carbon in reef corals. Mar. Biol. 15, 289-292.

DiSalvo, L. H., 1971a. Regenerative functions and microbial ecology of coral reefs: labelled bacteria in a coral reef microcosm. J. exp. mar. Biol. Ecol. 7, 123-136.

- 1971b. Regenerative functions and microbial ecology of coral reefs. I. Assays for microbial population. Can. J. Microbiol. 17, 1081-1089.

Franzisket, L., 1964. Die Stoffwechselintensität der Riffkorallen und ihre ökologische, phylogenetische und soziologische Bedeutung. Z. vergl. Physiol. 49, 91-113.

- 1969. The ratio of photosynthesis to respiration of reef building corals during a 24 hour period. Forma Functio. 1, 153-158.

Gordon, M. S. \& KelLy, H. M., 1962. Primary productivity of an Hawaiian coral reef: a critique of flow respirometry in turbulent waters. Ecology 43, 473-480.

Goreau, T. F., GorEAU, N. I. \& YoNGE, C. M., 1971. Reef corals: autotrophs of heterotrophs? Biol. Bull. mar. biol. Lab., Woods Hole 141, 247-260.

- - \& Neumann, Y., 1970. On the feeding and nutrition in Fungiacara eilatensis SootRYEN (Bivalvia, Mytilidae), a commensal living in fungiid corals. J. Zool. 160, 159-172.

JohanNes, R. E., 1967. Ecology of organic aggregates in the vicinity of a coral reef. Limnol. Oceanogr. 12, 189-195.

- Coles, S. L. \& Kunnzed, N. T., 1970. The role of zooplankton in the nutrition of some scleractinian corals. Limnol. Oceanogr. 15, 579-586.

Kanwisher, J. W. \& Wanwright, S. A., 1967. Oxygen balance in some reef corals. Biol. Bull. mar. biol. Lab., Woods Hole 133, 378-390.

KoHn, A. J. \& HeLfrich, P., 1957. Primary organic productivity of a Hawaiian coral reef. Limnol. Oceanogr. 2, 241-251.

Marshale, N., 1965. Detritus over the reef and its potential contribution to adjacent waters of Eniwetok Atoll. Ecology 46, 343-344.

Mrluiman, J. D. \& Mahnken, C. V. W., 1969. Reef productivity measurements. Atoll Res. Bull. 129, 23-41.

MusCATINE, L., 1972. Influence of zooxanthellae on productivity and calcification in reef corals: critique and perspectives. In: Symbiosis in the Sea. Ed. by W. B. Vernberg \& F. J. Vernberg. Univ. S. Carolina Press, Columbia. (In press).

- 1973. Nutrition of corals. In: Biology of coral reefs. Ed. by R. EndeAn. Acad. Press, New York 2 (In press). 
- \& Cernichiari, E., 1969. Assimilation of photosynthetic products of zooxanthellae by a reef coral. Biol. Bull. mar. biol. Lab., Woods Hole 137, 506-523.

- Poor, R. R. \& Cernichiari, E., 1972. Some factors influencing selective release of soluble organic material by zooxanthellae from reef corals. Mar. Biol. 13, 298-308.

Odum, E. P., 1971. Fundamentals of ecology. Saunders, Philadelphia. 574 pp.

Odum, H. T. \& Odum, E. P., 1955. Trophic structure and productivity of a windward coral reef community on Eniwetok Atoll. Ecol. Monogr. 25, 291-320.

- - 1959. Fundamentals of ecology. Saunders, Philadelphia, 546 pp.

- Burkholder, P. R. \& Rrvero, J., 1959. Measurements of productivity of turtle grass flats, reefs and the Bahia Fosforescente of Southern Puerto Rico. Publs. Inst. mar. Sci. Univ. Tex. 6, 159-170.

PARK, P. K., 1969. Oceanic $\mathrm{CO}_{2}$ system: An evaluation of ten methods of investigation. Limnol. Oceanogr. 15, 179-186.

Roffman, B., 1968. Patterns of oxygen exchange in some Pacific corals. Comp. Biochem. Physiol. 27, 405-418.

Sargent, M. C. 2 Austin, T. S., 1949. Organic productivity of an atoll. Trans. Am. geophys. Un. 30, 245-249.

- - 1954. Biologic economy of coral reefs. Prof. Pap. U.S. geol. Surv. 260-E, 293-300.

Smrtir, D., Muscatine, L. \& Lewis, D., 1969. Carbohydrate movement from autotrophs to heterotrophs in parasitic and mutualistic symbiosis. Biol. Rev. 44, 17-90.

SMITH, S. V., 1972. Eniwetok Atoll: CO2 system on a coral reef. Limnol. Oceanogr. (In press).

StOdDART, D. R., 1969: Ecology and morphology of recent coral reefs. Biol. Rev. 44, 433-498.

Strickland, J. D. H. \& Parsons, T. R., 1965. A manual of seawater analysis. Bull. Fish. Res. Bd Can. 125, 1-202.

TAYLOR, D. L., 1969. On the regulation and maintenance of algal numbers in zooxanthellaecoelenterate symbiosis, with a note on the relationship in Anemonia sulcata. J. mar. biol. Ass. U.K. 49, 1057-1065.

- 1971. On the symbiosis between Amphidinium klebsii (Dinophyceae) and Amphiscolops langerhansi (Turbellaria: Acoela). J. mar. biol. Ass. U.K. 51, 301-313.

- 1972. Symbiotic marine algae; taxonomy and biological fitness. In Symbiosis in the Sea. Ed. by W. B. Verneerg \& F. J. Verneerg. Univ. S. Carolina Press, Columbia. (In press).

- 1973. Cellular interactions of algal-invertebrate symbiosis. Adv. mar. Biol. 11 (In press).

TRENCH, R. K., 1971a. The physiology and biochemistry of zooxanthellae symbiotic with marine coelenterates. I. Assimilation of photosynthetic products of zooxanthellae by two marine coelenterates. Proc. R. Soc. (B) 177, 225-235.

- 1971b. The physiology and biochemistry of zooxanthellae symbiotic with marine coelenterates. II. Liberation of fixed ${ }^{14} \mathrm{C}$ by zooxanthellae in vitro. Proc. R. Soc. (B) 177, 237-250.

- 1971c. The physiology and biochemistry of zooxanthellae symbiotic with marine coelenterates. III. The effect of homogenates of host tissues on the excretion of photosynthetic products in vitro by zooxanthellae from two marine coelenterates. Proc. R. Soc. (B) 177, $251-264$.

Author's address: Professor D. L. TAyLoR

Rosenstiel School of Marine and Atmospheric Science

University of Miami

Miami, Florida 33149

USA 